DOI: $10.5800 / G T-2020-11-2-0474$

\title{
MICROMETEORITES FROM MODERN SEDIMENTS OF THE CENTRAL PART OF LAKE BAIKAL
}

\section{N.I. Akulov ${ }^{1}$, Y.G. Vologina ${ }^{1}$, L.A. Pavlova ${ }^{2}$, S.S. Vorobyova ${ }^{3}$}

${ }^{1}$ Institute of the Earth's Crust, Siberian Branch of RAS, Irkutsk, Russia

${ }^{2}$ A.P. Vinogradov Institute of Geochemistry, Siberian Branch of RAS, Irkutsk, Russia

${ }^{3}$ Limnological Institute, Siberian Branch of RAS, Irkutsk, Russia

ABSTRACT. The study is focused on micrometeorites from bottom sediments sampled from the Selenga-Buguldeika lintel of Lake Baikal. Their diatom analysis showed continuous sedimentation during the Holocene. Mineralogical analysis identified a complex of minerals, including micrometeorites, which amount to $0.6 \%$ of the heavy fraction weight. A detailed study of the micrometeorites was carried out using a JXA8200 electron probe x-ray microanalyzer. It was established that their chemical composition is predominantly represented by $\mathrm{Fe}, \mathrm{O}, \mathrm{C}$, and $\mathrm{Zn}$, i.e. these are type $1 \alpha$-micrometeorites. Based on the difference in the chemical composition of the micrometeorites in the sedimentary strata section, it is proposed to refer to such micrometeorites not only for stratigraphic correlations, but also for impact stratigraphy schemes.

KEYWORDS: micrometeorite; sand-silt sediments; diatom analysis; impact stratigraphy; Lake Baikal

FUNDING: This study was carried out under the state assignment of the Institute of the Earth's Crust SB RAS (Project 0346-2018-0004). 


\title{
МИКРОМЕТЕОРИТЫ ИЗ СОВРЕМЕННЫХ ОСАДКОВ ЦЕНТРАЛЬНОЙ ЧАСТИ ОЗЕРА БАЙКАЛ
}

\author{
Н.И. Акулов ${ }^{1}$, Е.Г. Вологина ${ }^{1}$, Л.А. Павлова ${ }^{2}$, С.С. Воробьёва ${ }^{3}$
}

\author{
${ }^{1}$ Институт земной коры СО РАН, Иркутск, Россия \\ ${ }^{2}$ Институт геохимии им. А.П. Виноградова СО РАН, Иркутск, Россия \\ 3 Лимнологический институт СО РАН, Иркутск, Россия
}

АннотАция. Приведены сведения о микрометеоритах из донных отложений, отобранных на Селенгино-Бугульдейской перемычке озера Байкал. Их диатомовый анализ показал, что формирование осадков происходило непрерывно в течение голоцена. Минералогический анализ позволил выявить в составе тяжелой фракции целый комплекс минералов, в том числе и микрометеориты. Количество микрометеоритов достигает 0.6 \% от веса тяжелой фракции. Проведено детальное изучение микрометеоритов с помощью электронно-зондового рентгеноспектрального микроанализатора JХА8200. Установлено, что их химический состав представлен преимущественно $\mathrm{Fe}, \mathrm{O}, \mathrm{C}$ и $\mathrm{Zn}$, что позволяет отнести их к $\alpha$-микрометеоритам 1-го типа. На основе различия химического состава микрометеоритов в разрезе осадочных толщ предложено использовать их не только для стратиграфической корреляции, но и для импакт-стратиграфических построений.

КЛЮчЕВЫЕ СЛОВА: микрометеорит; песчано-алевритовые осадки; диатомовый анализ; импакт-стратиграфия; озеро Байкал

ФИНАНСИРОВАНИЕ: Работа выполнена в рамках темы госзадания Института земной коры СО РАН (проект № 0346-2018-0004).

\section{1. ВВЕДЕНИЕ}

Основная масса внеземного вещества беспрерывно и повсеместно поступает на Землю в виде космической пыли, которая представлена твердыми частицами, в том числе и микрометеоритами, достигающими в поперечнике нескольких десятков микронов. Микрометеориты обладают высокой температурой плавления, поэтому проносятся через земную атмосферу практически без изменения, повсеместно и равномерно осаждаясь на поверхности Земли, что не только позволяет судить об их первичном составе, но и дает возможность использовать их при геологической корреляции и стратификации осадочных толщ.

Исследователи разных стран изучают микрометеориты в осадочных отложениях почти всех стратиграфических уровней. При этом важное место занимают осадочные слои, приуроченные к стратиграфическим рубежам крупнейших импактных событий на Земле. Внезапное и повсеместное вымирание на Земле древних организмов, вероятно, связано с геологическими катастрофами общепланетарного масштаба. Установлено, что гибель динозавров в конце мезозойской эры, а мамонтов - в кайнозойской совпадает со временем падения на Землю крупных астероидов [Keller et al., 2004; Keller, 2005]. Отмечено, что в осадочных слоях, сформировавшихся в эпоху вымирания динозавров и мамонтов, обнаружено большое количество микрометеоритов. Падение Челябинского болида также сопровождалось осаждением огромного количества микрометеоритов, основная масса которых вначале осела в снежном зимнем покрове, а после снеготаяния стала сноситься в различные зоны седиментации.
Современные знания о микрометеоритах не позволяют детально судить о приуроченности тех или иных микрометеоритов к осадочным пластам различных геологических эпох, так как исследователями только накапливаются данные об их химическом составе и особенностях строения. Вполне возможно, что в ближайшие годы, после создания банка данных по их химическому составу, будет разработана усовершенствованная импакт-стратиграфическая шкала. Группы микрометеоритов определенных типов или индикаторные микрометеориты позволят выполнить более детальное стратиграфическое расчленение, чем это сделано в настоящее время [Montanari, Koeberl, 2000; Korchagin, 2013]. Это связано с тем, что однотипные микрометеориты синхронно оседают в различных ландшафтных зонах земной поверхности, что в будущем может дать возможность проведения обширных межбассейновых, а возможно и общепланетарных схем корреляции осадочных образований морского, континентального и вулканогенно-осадочного генезиса. Происходит синхронное осаждение космической пыли в составе как терригенных и хемогенных осадков, так и вулканогенно-осадочных и органогенных образований. Таким образом, ее аккумуляция осуществляется практически во всех генетических типах пород, за исключением интрузивных и частично метаморфических. Следует отметить, что высокая температура плавления сфероидных микрометеоритов позволяет им сохраняться и в составе осадочных пород, прошедших стадию пирометаморфизма [Akulov et al., 2010, 2014a].

Исследования байкальских озерных отложений, проведенные за последние десятилетия, показали, что в их 
составе отражены не только палеоклиматические изменения, происходившие в регионе [Kuzmin et al., 2001; Akulov et al., 2005], но и фациальные условия заложения Байкальской рифтовой зоны, летопись которой началась 38 млн лет назад в озерно-болотных условиях Танхойского поля [Mashchuk, Akulov, 2012]. Таким образом, байкальские озерные отложения представляют собой непрерывный комплекс осадков, вмещающих микрометеориты, почти за всю кайнозойскую эру.

Для изучения современных микрометеоритов одни исследователи опробуют лед [Yada et al., 2004] или снег [Duprat et al., 2010; Bulat et al., 2012] в Антарктиде, другие проводят изучение торфяников в современных болотах [Tselmovich et al., 2016, 2019]. В настоящей статье представлены результаты исследования микрометеоритов из современных донных отложений озера Байкал. Цель изучения байкальских микрометеоритов связана как с вопросами седиментологии космического вещества в аквальных системах Земли, так и с познанием их строения, химического состава и возможности использования в стратиграфии и геологической корреляции.

\section{2. МАТЕРИАЛЫ И МЕТОДЫ ИССЛЕДОВАНИЙ}

В период летней экспедиции 2011 г. по озеру Байкал на научно-исследовательском судне “Титов” грунтовой трубкой UWITEC были отобраны многочисленные образцы современных донных отложений. Детальному вещественному анализу был подвергнут керн St. BAIK11-11, поднятый в районе Бугульдейской перемычки. Глубина озера в точке отбора равна 450 м, координаты станции $-52^{\circ} 26.547^{\prime}$ с. ш. $106^{\circ} 03.018^{\prime}$ в.д. (рис. 1).
Длина керна достигала 65 см, а его диаметр - 6.3 см. Колонки были разрезаны, сфотографированы. По ним было выполнено литологическое описание, сопровождаемое просмотром смер-слайдов и отбором образцов. Описание смер-слайдов проводилось на световом микроскопе марки SK14 (увеличение х 100) и включало определение основных родов ископаемых диатомовых водорослей и качественного гранулометрического состава терригенной составляющей осадков. С высокой степенью детальности проведен диатомовый анализ осадков по методике, описанной в работе [Grachev et al., 1997]. Проанализировано 64 пробы, шаг опробования по керну составил 1 см.

Методика исследования байкальских микрометеоритов была апробирована при изучении плейстоценовых отложений [Akulov et al., 2014b, 2015a, 2015b]. При этом определение гранулометрического состава донных осадков выполнено по пробам весом 30 г, отобранным в интервалах 0-5 см, 10-15 см, 20-25 см и 4045 см от поверхности дна озера из исследуемого керна (рис. 2). Глинистая фракция выделена методом отмучивания в дистиллированной воде, а деление песчаноалевритового материала на классы проведено путем его рассеивания на ситах. Гранулометрический класс 0.25-0.05 мм был подвергнут детальному минералогическому анализу. Минералы легкой и тяжелой фракций разделялись с помощью бромоформа. Их дальнейшее изучение осуществлялось в иммерсионных препаратах. Из минералов тяжелой фракции методом магнитной сепарации были отобраны магнитные минералы, из которых под бинокуляром извлечены микрометеориты.

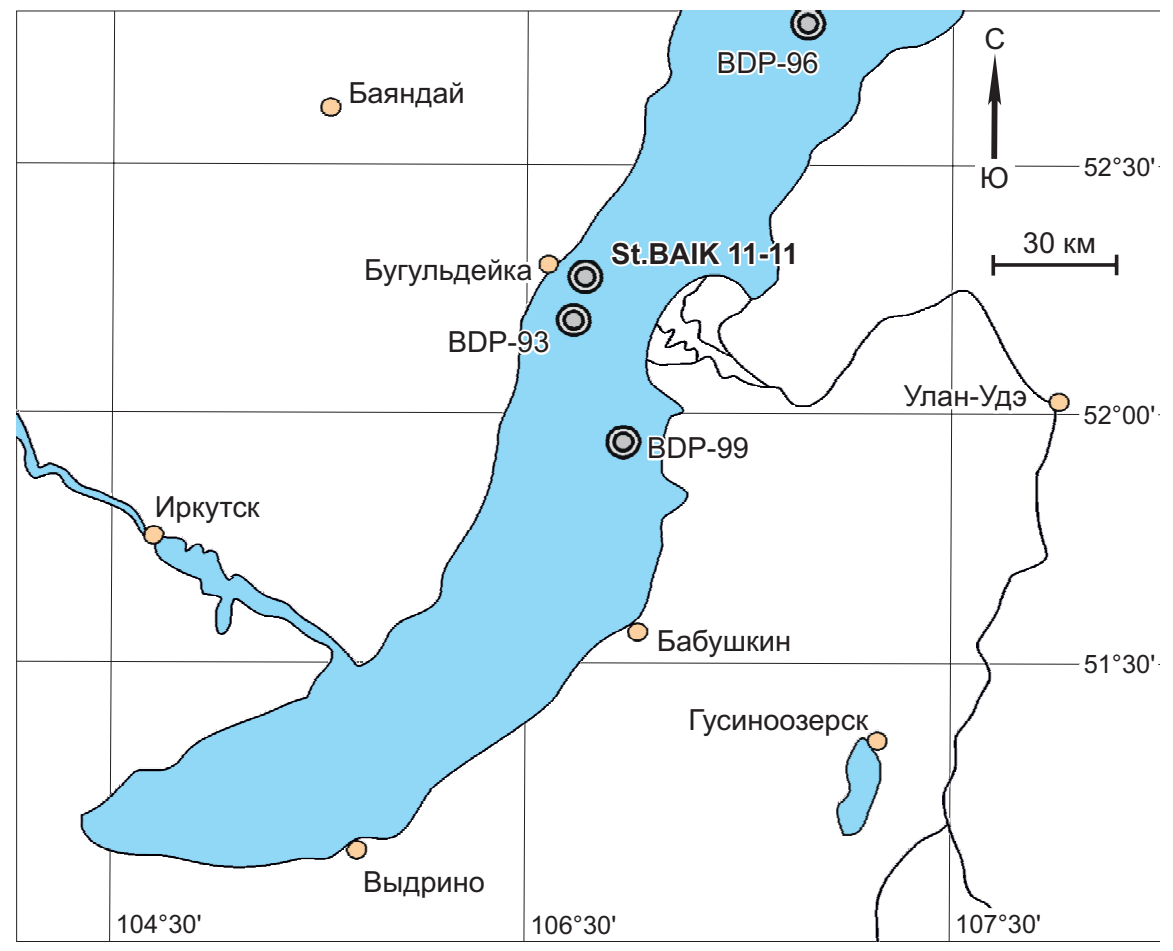

Pис. 1. Схема расположения станции отбора керна (St. BAIK11-11) на Бугульдейской перемычке озера Байкал.

Fig. 1. Location of the coring station (St. BAIK11-11) on the Buguldeika lintel of Lake Baikal. 


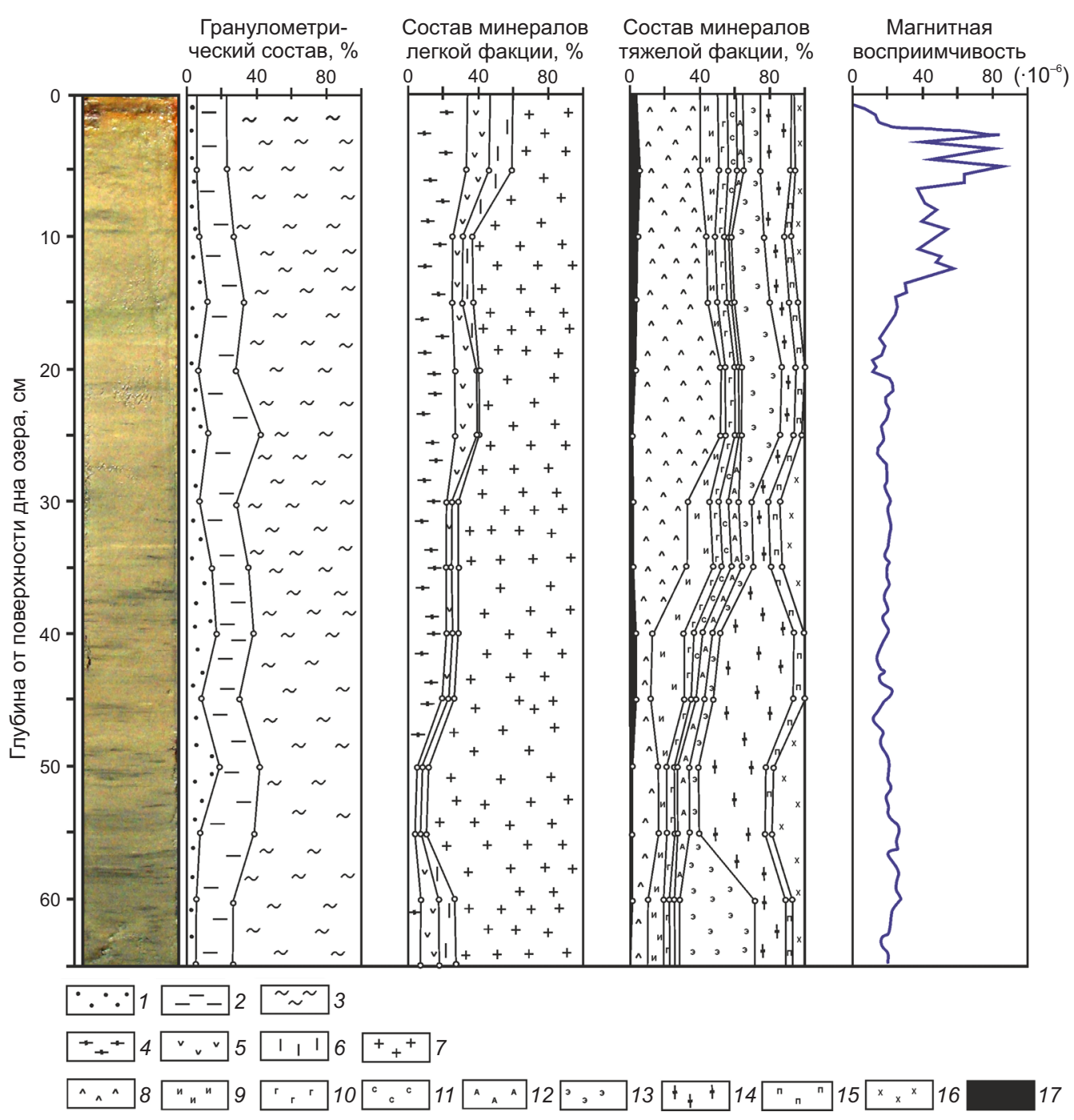

Рис. 2. Вещественный состав донных отложений по разрезу St. BAIK11-11.

1-3 - гранулометрические фракции: 1 - песчаная (0.50-0.05 мм), 2 - алевритовая (0.050-0.005 мм), 3 - пелитовая (менее 0.005 мм); 4-7 - состав минералов легкой фракции: 4 - кварц, 5 - плагиоклазы и полевые шпаты, 6 - слюды, 7 - диатомовые водоросли, цисты золотистых водорослей и спикулы губок; 8-16- состав минералов тяжелой фракции: 8 - магнетит, 9 - ильменит, 10 - гранаты, 11 - сфен, 12 - амфиболы, 13 - эпидот, 14 - гётит, 15 - пирит, 16 - турмалин, циркон, лейкоксен, апатит и ставролит; 17 - микрометеориты.

Fig. 2. Material composition of bottom sediments in the St. BAIK11-11 section.

1-3 - granulometric fractions: 1 - sandy $(0.50-0.05 \mathrm{~mm}), 2$ - aleuritic $(0.050-0.005 \mathrm{~mm}), 3$ - pelitic (less than $0.005 \mathrm{~mm}) ; 4-7-$ composition of light fraction minerals: 4 - quartz, 5 - plagioclase and feldspar, 6 - mica, 7 - diatoms, golden algae cysts, and sponge spicules; 8-16 - compositions of heavy fraction minerals: 8 - magnetite, 9 - ilmenite, 10 - garnet, 11 - sphene, 12 - amphibole, 13 epidote, 14 - goethite, 15 - pyrite, 16 - tourmaline, zircon, leucoxene, apatite, and staurolite; 17 - micrometeorites.

На электронно-зондовом рентгеноспектральном микроанализаторе JХА8200 проанализировано 15 микрометеоритов. Результаты анализов, полученные с помощью микроанализатора ЈХА8200, приведены в массовых процентах, а минералогического и диатомового - в количественных.

\section{3. ПОЛУЧЕННЫЕ РЕЗУЛЬТАТЫ И ОБСУЖДЕНИЕ}

Бугульдейская перемычка разделяет Южную и Среднюю котловины озера и представляет собой приподнятый участок дна оз. Байкал, образованный главным образом отложениями p. Селенги [Kuzmin et al., 2001].
Современное осадконакопление на ее площади происходит в сравнительно спокойных условиях. Скорости осадконакопления достаточно высоки - от 0.2 [Kuzmin et al., 2001] до 0.86 мм/год [Vologina, Sturm, 2009]. В связи с этим Бугульдейская перемычка является одним из районов Байкала, где можно проводить высокоразрешающие исследования донных отложений как для реконструкции условий современного осадконакопления, так и для изучения космического вещества, поступающего в виде микрометеоритов.

По данным литологического изучения донные отложения, вскрытые грунтовой трубкой, представлены 
биогенно-терригенными илами. Биогенная часть илов состоит главным образом из створок диатомей, цист золотистых водорослей и спикул губок. Терригенная составляющая представлена глинами и минеральными зернами алевритовой и песчаной размерности. Верхняя часть вскрытого разреза окислена. Окисленные осадки имеют темно-коричневый цвет, мощность окисленной зоны составляет 2 см. Детальное исследование текстурно-структурных особенностей керна позволило установить, что вскрытая часть донных отложений имеет отчетливую горизонтальную слоистость. Следы подводного размыва и турбидиты отсутствуют, что свидетельствует о спокойных гидродинамических условиях, в которых происходило осадконакопление.

С помощью гранулометрического анализа (рис. 2) установлено, что исследуемые осадки представляют собой смешанный тип отложений, которые состоят из глин (63.8-78.2\%), алевритов (16.8-29.0 \%) и песков (4.0-10.5 \%). Песок представлен преимущественно тонкозернистыми разностями (до 9.8 \%), мелкозернистый материал не превышает $0.7 \%$. В интервалах 10-15 см и 20-25 см донные отложения содержат среднезернистый песок (0.7 и $0.6 \%$ соответственно). Для этих интервалов также характерен повышенный выход минералов тяжелой фракции - 1.2 и $3.8 \%$ соответственно. Анализ легкой фракции донных осадков показал наличие кварца, плагиоклаза, калиевых полевых шпатов, слюды (биотита и мусковита). В незначительных количествах присутствуют вивианит (до $0.4 \%$ ), графит (единичные знаки), спикулы губок (до 0.8 \%), углефицированные растительные остатки (до $0.4 \%$ ) и хлорит (единичные знаки в интервале 0-5 см). Во всех пробах присутствует большое количество створок диатомей (16.8-58.0 \%). Минералы тяжелой фракции представлены магнетитом (11.8-51.6\%), пиритом (0.2-47.6\%), гетитом (3.0$42.4 \%)$, ильменитом (1.6-16.6\%), гематитом (1.2-12.0\%), эпидотом (1.2-10.2\%), роговой обманкой (1.0-9.2\%), гранатом (0.8-7.4\%), сфеном (1.0-7.0\%), пироксенами (0.2-3.6\%), турмалином (0-2.2\%), цирконом (0.2-1.2\%), лейкоксеном (0-1.0 \%). В незначительных количествах присутствуют апатит, микрометеориты, биотит, рутил, брукит, ставролит и силлиманит (рис. 2).

Проведенное изучение магнитной восприимчивости осадков показало, что она существенно изменяется в зависимости от содержания минералов тяжелой фракции. Магнитные свойства исследуемых образцов керна обусловлены наличием в составе осадков магнитных минералов (титаномагнетитовый и гемоильменитовый ряды) и микрометеоритов. Обнаружено, что максимальное значение магнитной восприимчивости приурочено к приповерхностным отложениям, содержащим наибольшее количество магнетита и микрометеоритов (ММ).

Результаты диатомового анализа. Обнаружено 144 вида и разновидности диатомей, из них 28 - планктонные из 7 родов и 116 - бентосные из 32 родов (рис. 3). Общее содержание планктонных диатомей в разрезе достигает 102.4-300.4 миллионов створок на грамм сухого осадка (млн створок/г); бентосных - 0.98-4.03 млн створок/г (0.4-2.1\%). В осадках встречались цисты золотистых водорослей (5.5-36.3 миллионов экземпляров на грамм сухого осадка) и спикулы губок (до 1050 тысяч экземпляров/г).

Численность и состав диатомей варьируются по разрезу. На глубине 55-64 см преобладают створки Synedra acus et var. (12.9-60.3\%), Cyclotella minuta (18.6-52.5\%), Stephanodiscus meyerii (8.7-25.0\%), Aulacoseira baicalensis (2.6-11.1\%), A. islandica со спорами (1.7-9.4\%). В интервале 51-54 см возросла роль Cyclotella minuta (72.789.8 \%) и C. baicalensis (2.9-5.7 \%). На глубине 43-50 см содержание этих диатомей снизилось до 20.9-80.2 и 0.83.1 \% соответственно. Здесь также отмечалась высокая доля створок Stephanodiscus meyerii (5.2-40.3 \%), Synedra acus et var. (1.3-28.5\%), Aulacoseira baicalensis (2.614.7 \%). Интервал 32-42 см характеризовался заметным обилием Cyclotella minuta (44.3-90.5 \%) и Stephanodiscus meyerii (3.5-42.3 \%). На глубине 9-31 см преобладала $C y$ clotella minuta (80.7-96.8\%), а в придонном слое (0-8 cм) ее численность снизилась до 31.9-74.1 \%, но увеличилось обилие Stephanodisus meyerii (5.3-39.2\%), Synedra acus et var. (2.5-31.9\%), Aulacoseira baicalensis (8.6$26.8 \%$ ), Aulacoseira islandica со спорами (2.2-9.6 \%). В небольшом количестве (0.01-0.44 млн створок/г) присутствуют Aulacoseira ambigua, A. granulata, A. subarctica, Cyclostephanos dubius, Synedra ulna var. danica, мелкоклеточные виды рода Stehanodiscus. Периодически встречались створки Melosira varians, Ellerbeckia arenaria forma teres. В заметном количестве (0.1-0.9 млн створок/г) наблюдаются бентосные диатомеи - виды родов Fragilaria, Cocconeis, Opephora, Gomphonema, Hannaea, Achnanthes, в основном обрастатели. Отмечается присутствие древних переотложенных видов миоцен-плейстоценового возраста (10 таксонов) с невысокой численностью (0.01-0.14 млн створок/г, или 0.01-0.07 \%).

Полученные результаты диатомового анализа свидетельствуют об отсутствии перерывов осадконакопления в данном разрезе и указывают на голоценовый возраст этих отложений, что хорошо согласуется с ранее опубликованными палинологическими данными [Vologina, Kulagina, 2014].

Детальные исследования микрометеоритов позволили выявить, что они имеют сферическую или близкую к ней форму и обладают магнитными свойствами, поэтому их можно называть магнитными сфероидами (рис. 4). При 800-кратном увеличении установлено, что сфероиды имеют относительно неровную поверхность, покрытую сложным графическим рисунком. Лишь некоторые микрометеориты имеют идеально гладкую поверхность. Их диаметр колеблется в пределах от 26 до 91 мкм, а медианный диаметр равен 62 мкм. Особый интерес представляют частично разрушенные микрометеориты, подобные изученному нами микрометеориту № 9 (рис. 4). На его хрупком изломе видны прямоугольные грани раскристаллизованного микрокристалла. Наиболее вероятная причина появления подобных сколов связана с избирательной коррозией, 


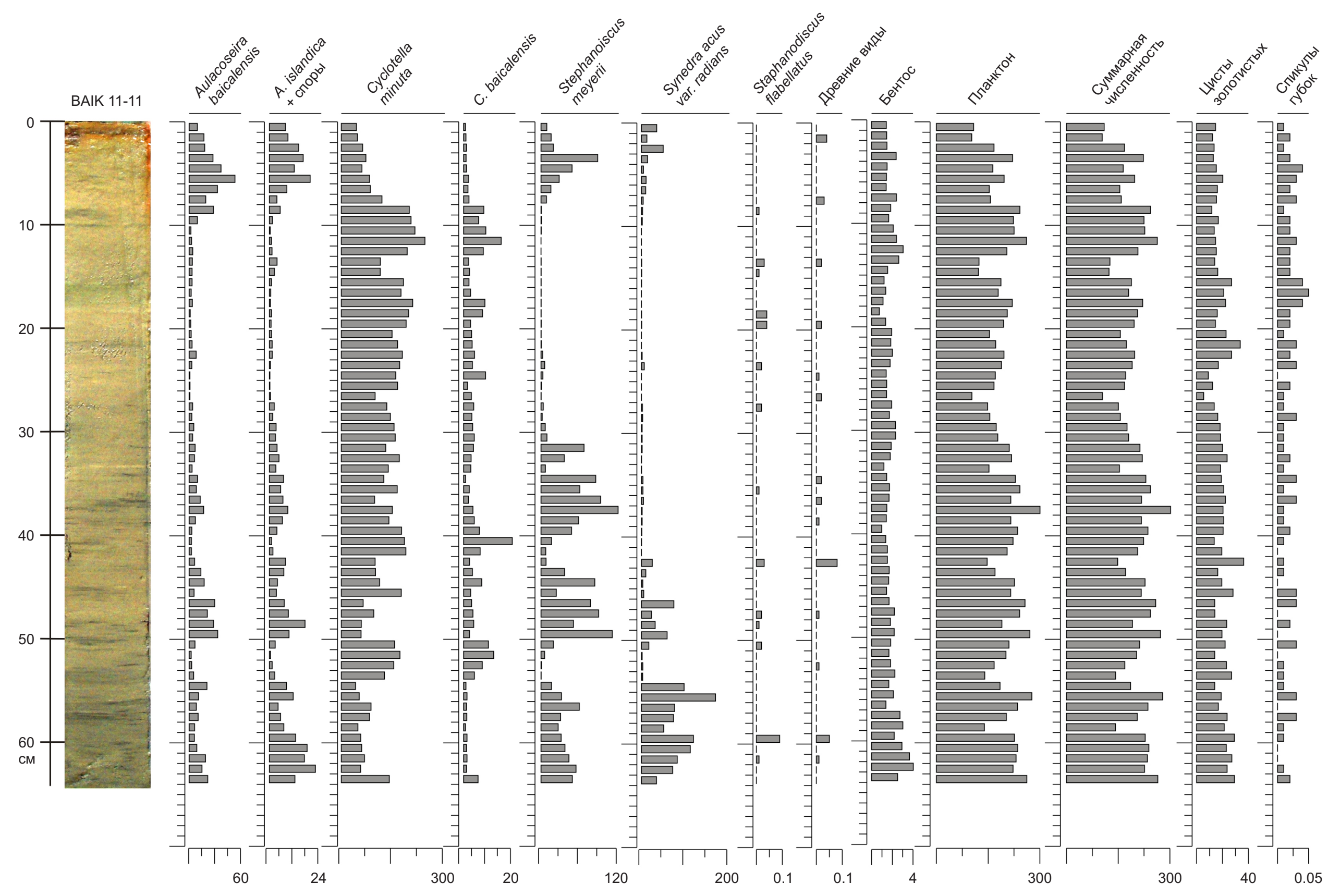

Рис. 3. Распределение диатомовых водорослей (млн створок / г), цист золотистых водорослей и спикул губок (млн экземпляров / г) по разрезу ВАІК11-11.

Fig. 3. Distribution of diatoms ( $\mathrm{mln} / \mathrm{g}$ ), golden algae cysts and sponge spicules ( $\mathrm{mln} / \mathrm{g}$ ) along the BAIK11-11 section. 
которая прошла вдоль границы микрокристаллов металлического сплава.

По сведениям В.М. Иванова [Ivanov, 1990], избирательная коррозия соединений металлов характерна для обесцинкованных латунных сплавов. В результате потери цинка железо-медистые (латунные) сплавы становятся хрупкими и легко разрушаются. Вполне возможно, что такое коррозионное растрескивание обусловило наблюдаемый хрупкий излом в виде скола микрометеорита. По всей видимости, это происходит в процессе взаимодействия коррозионной водной среды озера и внутренних микрометеоритных напряжений, приводящих к появлению трещин, которые обладают межкристаллитным, транскристаллитным или смешанным характером. Важно отметить, что изначально они концентрируются на локальном участке сфероидов, что приводит к их частичному скалыванию и последующему разрушению.

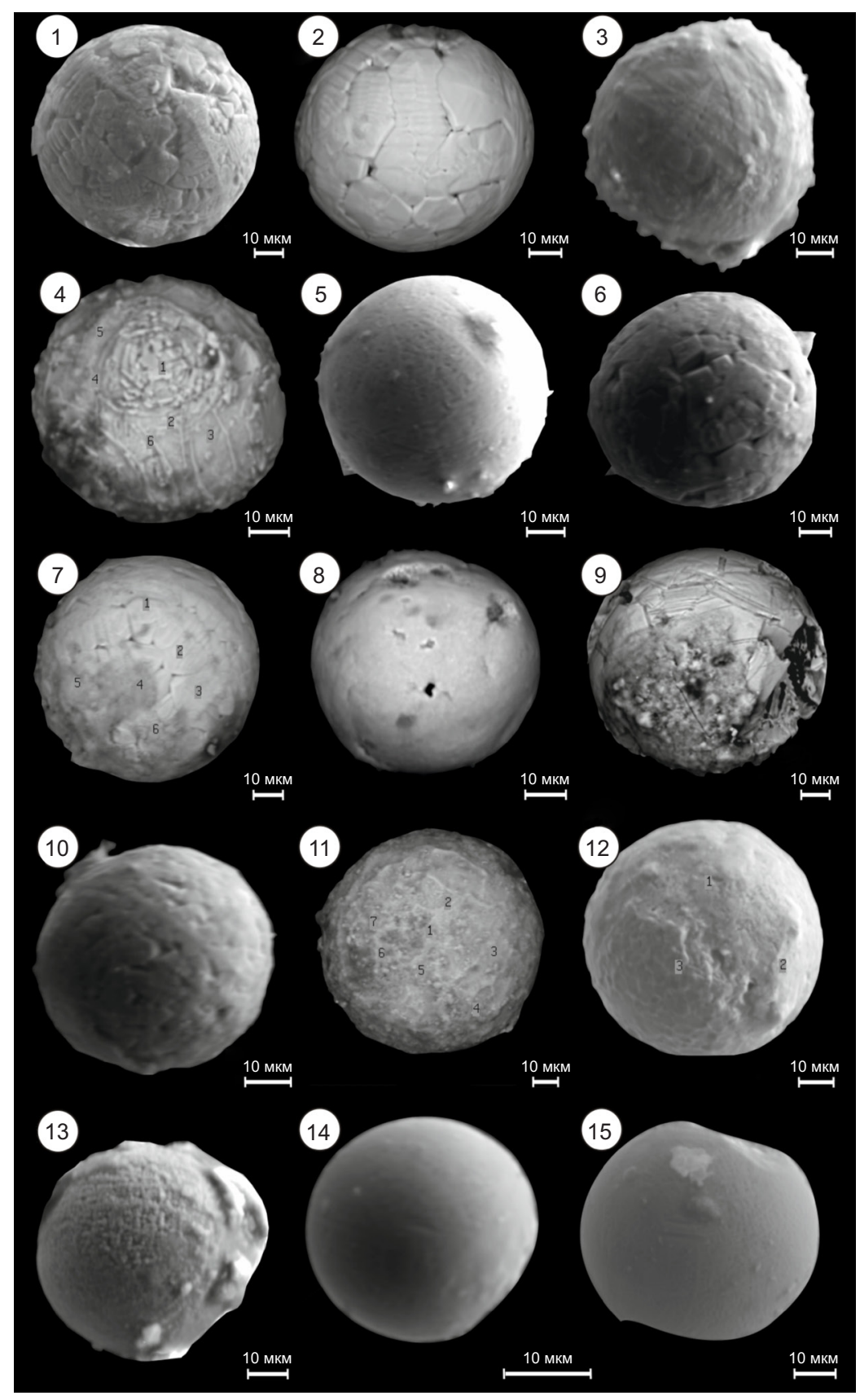

Рис. 4. Микрометеориты из современных осадков озера Байкал.

1-15 - номера микрометеоритов (здесь и на рис. 5 и 6): 1-4 - отобранные на глубине 0-5 см; 5-10 - на глубине 20-25 см; 11-15 - на глубине 40-45 см.

Fig. 4. Micrometeorites from modern sediments of Lake Baikal.

1-15 -micrometeorite numbers (here and in Fig. 5 and 6): 1-4 - sampled from the depth of 0-5 cm; 5-10- depth of 20-25 cm; 11-15 depth of $40-45 \mathrm{~cm}$. 


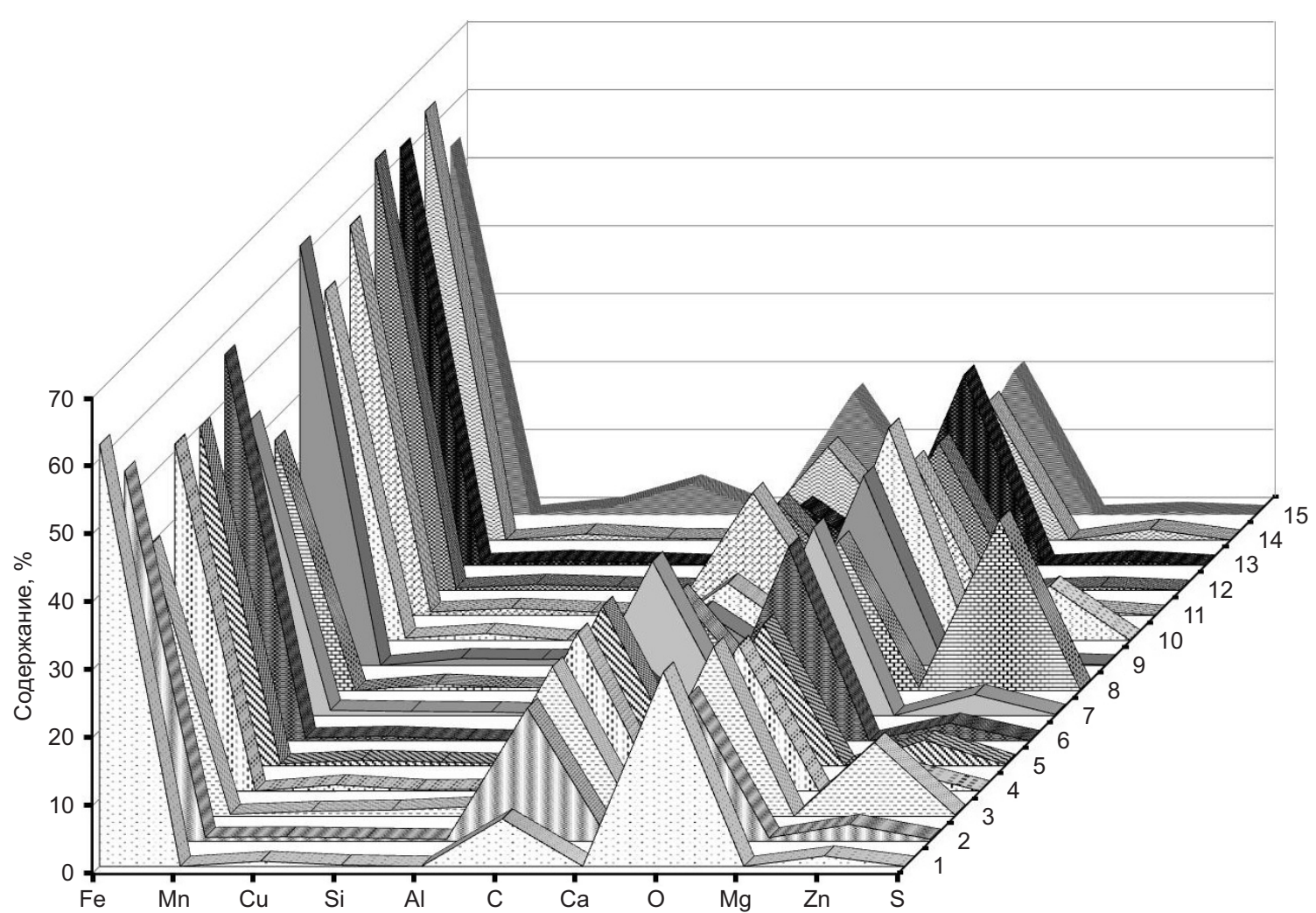

Рис. 5. Химический состав микрометеоритов из современных донных осадков озера Байкал, определенный с помощью энергодисперсионного спектрометра EX-84055MU (JEOL Ltd, Япония) на электронно-зондовом рентгеноспектральном микроанализаторе JXА8200. Порядковые номера микрометеоритов, внешний облик которых показан на рис. 4, приведены на внешней стороне диаграммы.

Fig. 5. Chemical compositions of micrometeorites from modern bottom sediments of Lake Baikal, determined using an EX-84055MU energy dispersive spectrometer (JEOL Ltd, Japan) on a JXA8200 electron probe X-ray microanalyzer. The serial numbers of micrometeorites (see Fig. 4) are listed outside the diagram.

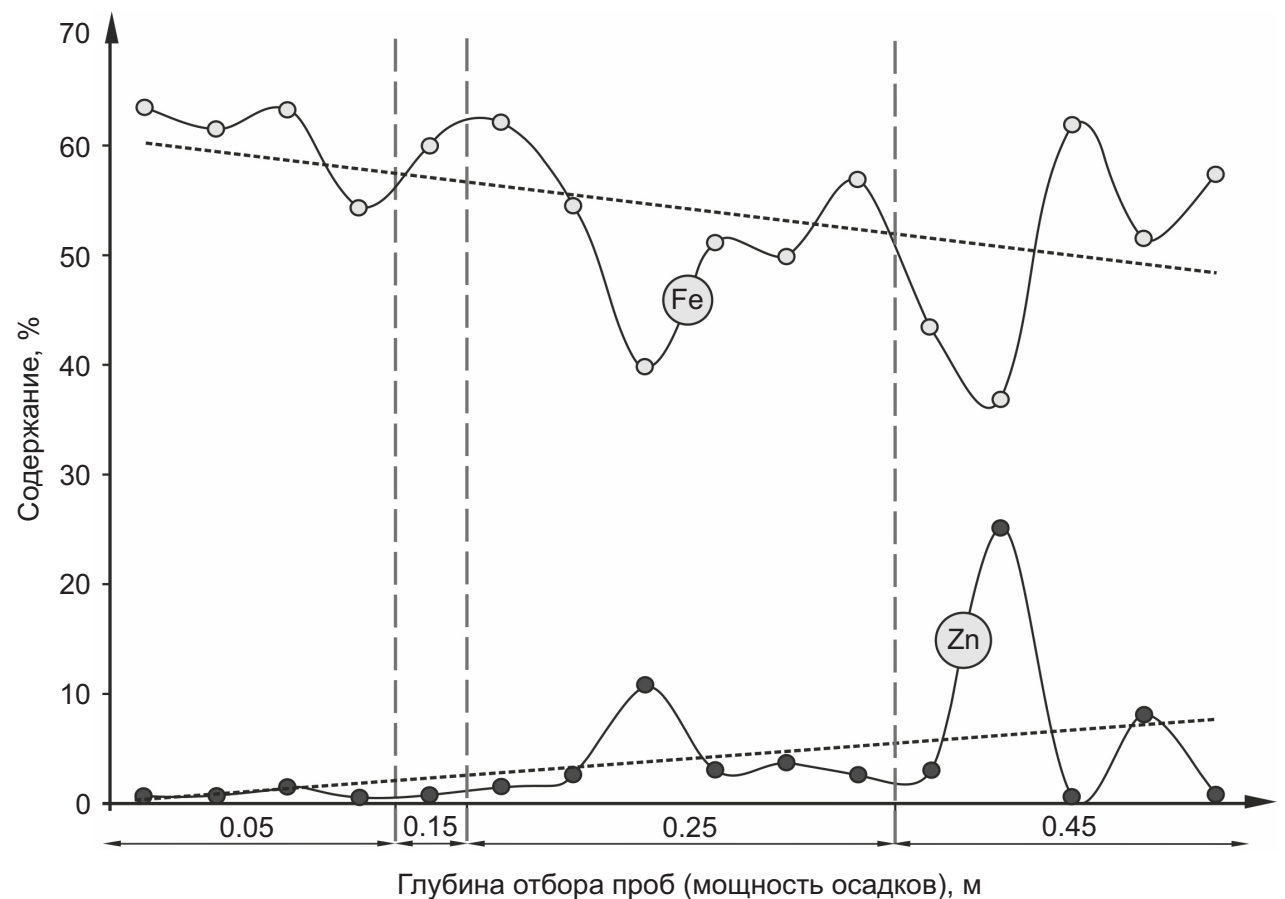

Рис. 6. Динамика изменения осредненных значений Fe и Zn в составе микрометеоритов по разрезу St. BAIK11-11.

Fig. 6. Dynamics of changes in the averaged values of Fe and $\mathrm{Zn}$ in the compositions of micrometeorites along the St. BAIK11-11 section. 
Анализ микрометеоритного материала. На электронно-зондовом рентгеноспектральном микроанализаторе JXА8200 проанализировано 15 микрометеоритов, по которым выполнено 126 микрозондовых химических анализов.

Установлено, что они состоят из Fe, O, C и Zn (рис. 5). Содержания Fe 25.7-72.6 \%, 0 1.3-38.2 \%, C 4.3-53.1 \%, Zn 0.1-32.1\%. Это типичные цинково-железистые микрометеориты. Согласно общепринятой классификации [Korchagin, 2013] изученные сфероиды относятся к $\alpha$-микрометеоритам 1-го типа, так как железо занимает основное место в их составе. Кроме того, некоторые из них содержат $\mathrm{Si}$ (до 4.5 \%), Cu (до 1.59\%), Al (до 1.76 \%). В незначительных количествах присутствуют $\mathrm{Mn}, \mathrm{Mg}$, Са и S.

По данным микрозондовых анализов обнаружено, что сверху вниз по разрезу донных осадков общий тренд содержания железа в исследуемых микрометеоритах падает, а цинка - возрастает (рис. 6).

Важно отметить, что согласно ранее проведенным исследованиям голоценовых осадков из скважины BDP-93 (интервал 0-18.0 м от поверхности дна; см. рис. 1), пройденной на Бугульдейской банке озера Байкал, были извлечены микрометеориты, которые по данным микрозондовых анализов также состоят из Zn и Fe [Akulov et al., 2015a]. Кроме того, в процессе буровых работ по проекту «Байкал-бурение» на Академическом хребте из керна скважины BDP-96 были получены сведения о химическом составе современных микрометеоритов, которые также имели цинково-железистый состав [Akulov et al., 2014b, 2015b].

Текстура микрометеоритов обусловлена формой и характером срастания минеральных образований. Микрометеориты обладают массивной и графической текстурой.

Таким образом, однотипность микрометеоритов в современных отложениях, удаленных друг от друга на десятки километров, подтверждает идею об их площадном распространении и по крайней мере может выступать в качестве корреляционного индикатора голоценовых осадков на озере Байкал.

\section{4. ЗАКЛЮЧЕНИЕ}

Проведенные исследования позволяют сделать следующие выводы.

Выполненный детальный диатомовый анализ свидетельствует о позднеголоценовом возрасте изученных осадков и непрерывности их накопления.

Исследованные отложения озера Байкал содержат космическую пыль в виде сфероидных микрометеоритов, количество которых достигает 0.6 \% от объема минералов тяжелой фракции осадков.

Все изученные микрометеориты имеют цинковожелезистый состав и относятся к $\alpha$-микрометеоритам 1-го типа.

Наблюдается обратно пропорциональная зависимость содержания железа и цинка по керну в направлении от молодых осадков к более древним. Тренд содержания железа в исследуемых микрометеоритах падает, а цинка - возрастает.

Повсеместное распространение космической пыли открывает перспективы использования однотипных микрометеоритов для стратиграфической корреляции.

\section{5. БЛАГОДАРНОСТИ}

Авторы благодарны Е.Г. Поляковой и С.П. Сумкиной за проведение минералогического и гранулометрического анализа донных осадков, а также Т.О. Железняковой за помощь в выполнении диатомового анализа. Работа выполнена в рамках темы госзадания Института земной коры СО РАН (проект № 0346-2018-0004) «Новейшая геодинамика, геосферные и биосферные эволюционные и катастрофические природные изменения».

\section{6. ЛИТЕРАТУРА / REFERENCES}

Akulov N.I., Agafonov B.P., Lomonosova T.K., Vologina E.G., 2005. The Lithological Composition of Modern Sandy Sediments of Lake Baikal. Lithology and Minerals 2, 133-142 (in Russian) [Акулов Н.И., Агафонов Б.П., Ломоносова Т.К., Вологина Е.Г. Литологический состав современных песчаных отложений Байкала // Литология и полезные ископаемые. 2005. № 2. С. 133-142].

Akulov N.I., Akulova V.V., Khudonogova E.V., 2010. Pyrogenic Metamorphism of the Carbonaceous Rocks in the South of the Siberian Platform. In: Coal Combustion Research. Editor Christopher T. Grace. Nova Science Pub Inc., New York, p. 219-234.

Akulov N.I., Amirzhanov A.A., Akulova V.V., Khudonogova E.V., 2014a. Pyrometamorphism of Technogenic Redeposited Coal-Bearing Rocks of Heaps: Pyrometamorphic Jasperoids. Bulletin of the Irkutsk State Technical University 5, 44-52 (in Russian) [Акулов Н.И., Амиржанов А.А., Акулова В.В., Худоногова Е.В. Пирометаморфизм техногенно-переотложенных угленосных пород терриконов: пирометаморфические яшмоиды // Вестник ИРГТУ. 2014. № 5. C. 44-52].

Akulov N.I., Antipin E.V., Pavlova L.A., 2015a. Micrometeorites from the Upper Pleistocene Sediments of Lake Baikal. Izvestia. Siberian Branch of the Section of Earth Sciences of the Russian Academy of Natural Sciences. Geology, Prospecting and Exploration of Ore Deposits 52 (3), 94-104 (in Russian) [Акулов Н.И., Антипин Е.В., Павлова Л.А. Микрометеориты из верхнеплейстоценовых отложений озера Байкал // Изв. Сибирского отделения Секции наук о Земле Российской академии естественных наук. Геология, поиски и разведка рудных месторождений. 2015. Т. 52. № 3. С. 94-104].

Akulov N.I., Mashchuk I.M., Akulova V.V., 2015b. Pleistocene Sediments of Lake Baikal: Lithology and Stratigraphic Correlation. Stratigraphy and Geological Correlation 23, 94113. https://doi.org/10.1134/S0869593815010025.

Akulov N.I., Pavlova L.A., Antipin E.V., 2014b. Geochemical Features of Micrometeorites in the Bottom Sediments of Lake Baikal. Reports of the Academy of Sciences 454 (6), 695700 (in Russian) [Акулов Н.И., Павлова Л.А., Антипин Е.В. 
Геохимические особенности микрометеоритов в донных отложениях озера Байкал // Доклады АН. 2014. Т. 454. № 6. С. 695-700]. https://doi.org/10.7868/S0869 565214060164.

Bulat E.S., Tselmovich V.A., Bulat S.A., 2012. Central East Antarctica as an Ideal Natural Tablet for Collecting Cosmic Dust: Preliminary Results. In: Astrobiology: from the Origin of Life on Earth to Life in the Universe. Proceedings of the 1st All-Russia Scientific School-Conference (September 16-19, 2012, Pushchino). P. 184 (in Russian) [Булат Е.С., Цельмович В.А., Булат С.А. Центральная Восточная Антарктида как идеальный природный планшет для сбора космической пыли: предварительные результаты / Астробиология: от происхождения жизни на Земле к жизни во Вселенной: Материалы 1-й Всероссийской научной школы-конференции по астробиологии (16-19 сентября 2012, Пущино). С. 184].

Duprat J., Dobrica E., Engrand C., Aleon J., Marrocchi Y., Mostefaoui S., Meibom A., Leroux H., Rouzaud J.-N., Gounelle M., Robert F., 2010. Extreme Deuterium Excesses in Ultracarbonaceous Micrometeorites from Central Antarctic Snow // Science 328, 742-745 https://doi.org/10.1126/ science.1184832.

Grachev M.A., Likhoshvay E.V., Vorobyova S.S., Khlystov O.M., Bezrukova E.V., Veinberg E.V., Goldberg E.L., Granina L.Z., Kornakova E.G., Lazo F.I., Levina O.M., Letunova P.P., Otinov P.V., Pirog V.V., Fedotov A.P., Yaskevich S.A., Bobrov V.A., Sukhorukov F.V., Rezchikov V.I., Fedorin M.A., Zolotarev K.V., Kravchinsky V.A., 1997. Paleoclimate Signals of the Upper Pleistocene in Sediments of Lake Baikal. Geology and Geophysics 38 (5), 957-980 (in Russian) [Грачев М.А., Лихошвай Е.В., Воробьева С.С., Хлыстов О.М., Безрукова Е.В., Вейнберг Е.В., Гольдберг Е.Л., Гранина Л.З., Корнакова Е.Г., Лазо Ф.И., Левина О.М., Летунова П.П., Отинов П.В., Пирог В.В., Федотов А.П., Яскевич С.А., Бобров В.А., Сухоруков Ф.В., Резчиков В.И., Федорин М.А., Золотарев К.В., Кравчинский В.А. Сигналы палеоклиматов верхнего плейстоцена в осадках озера Байкал // Геология и геофизика. 1997. Т. 38. № 5. С. 957-980].

Ivanov V.N., 1990. Foundry Dictionary. Mechanical Engineering, Moscow. 384 р. [Иванов В.Н. Словарь-справочник по литейному производству. М.: Машиностроение. 1990. 384 с.].

Keller G., 2005. Impacts, Volcanism and Mass Extinctions: Random Coincidence or Cause and Effect? Australian Journal of Earth Sciences 52, 725-757. https://doi.org/10.1080/ 08120090500170393.

Keller G., Adatte T., Stinnesbeck W., Stuben D., Berner Z., Kramar U., Harting M., 2004. More Evidence that the Chicxulub Impact Predates the K/T Mass Extinction. Meteoritics and Planetary Science 39, 1127-1144. https: //doi.org/10. 1111/j.1945-5100.2004.tb01133.x.

Korchagin O.A., 2013. Fossil Micrometeorites, Microtectites and Microcristites: Research Methodology, Classification and Impact-Stratigraphic Scale. In: Stratigraphy at the Beginning of the XXI Century - Trends and New Ideas. Essays on the Regional Geology of Russia. GEOS, Moscow. Issue 6, p. 112-142 (in Russian) [Корчагин О.А. Ископаемые микрометеориты, микротектиты и микрокриститы: методика исследований, классификация и импакт-стратиграфическая шкала / Стратиграфия в начале XXI века тенденции и новые идеи. Очерки по региональной геологии России. М.: ГЕОС. 2013. Вып. 6. С. 112-142].

Kuzmin M.I., Karabanov E.B., Kawai T., William D., Bychinsky V.A., Kerber E.V., Kravchinsky V.A., Bezrukova E.V., Prokopenko A.A., Geletiy V.F., Kalmychkov G.V., Goreglyad A.V., Antipin V.S., Khomutova M.Yu., Soshina N.M., Ivanov E.V., Khursevich G.K., Tkachenko L.L., Solotchina E.P., Yoshida N., Gvozdkov A.N., 2001. Deepwater Drilling on Baikal - the Main Results. Geology and Geophysics 42 (1-2), 8-34 (in Russian) [Кузьмин М.И., Карабанов Е.Б., Каваи Т., Вильям Д., Бычинский В.А., Кербер Е.В., Кравчинский В.А., Безрукова Е.В., Прокопенко А.А., Гелетий В.Ф., Калмычков Г.В., Горегляд А.В., Антипин В.С., Хомутова М.Ю., Сошина Н.М., Иванов Е.В., Хурсевич Г.К., Ткаченко Л.Л., Солотчина Э.П., Йошида Н., Гвоздков А.Н. Глубоководное бурение на Байкале - основные результаты// Геология и геофизика. 2001. Т. 42. № 1-2. С. 8-34].

Mashchuk I.M., Akulov N.I., 2012. Oligocene Sediments of the Baikal Rift Basin. Geology and Geophysics 53 (4), 461-476 (in Russian) [Мащук И.М., Акулов Н.И. Олигоценовые отложения Байкальской рифтовой впадины // Геология и геофизика. 2012. Т. 53. № 4. С. 461-476].

Montanari A., Koeberl C., 2000. Impact Stratigraphy: the Italian Record, Berlin, Heidelberg, New York, Barcelona, Hong Kong, London, Milan, Paris, Singapore, Tokyo: Springer. $371 \mathrm{p}$.

Tselmovich V.A., Kurazhkovsky A.Yu., Kazansky A.Yu., Shchetnikov A.A., Blyakharchuk T.A., Amelin I.I., 2016. Investigation of peat deposits in studies of catastrophic events of the Holocene. In: Paleomagnetism and Rock Magnetism. Proceedings of the All-Russian School-Seminar. Filigree, Yaroslavl, p. 148-153 (in Russian) [Цельмович B.A., Куражковский А.Ю., Казанский А.Ю., Щетников А.А., Бляхарчук Т.А., Амелин И.И. Использование торфяных отложений для исследования катастрофических событий в голоцене // Палеомагнетизм и магнетизм горных пород: Материалы Всероссийской школы-семинара. Ярославль: Филигрань. 2016. С. 148-153].

Tselmovich V.A., Kurazhkovsky A.Yu., Kazansky A.Yu., Shchetnikov A.A., Blyakharchuk T.A., Filippov D.A., 2019. Research on the Dynamics of Cosmic Dust on the Earth's Surface by Studying Peat Deposits. Physics of the Earth 3, 15-23 (in Russian) [Цельмович В.А., Куражковский А.Ю., Казанский А.Ю., Щетников., А.А., Бляхарчук Т.А., Филиппов Д.А. Исследования динамики поступления космической пыли на земную поверхность по торфяным отложениям. Физика Земли. 2019. № 3. C. 15-23]. https:// doi.org/10.31857/S0002-333720193150-160.

Vologina E.G., Kulagina N.V., 2014. Characterization of Surface Sediments of the Buguldeika Lintel of Lake Baikal. Bulleting of the Irkutsk State University. Earth Sciences Series 10, 57-66 (in Russian) [Вологина Е.Г., Кулагина Н.В. Характеристика поверхностных осадков Бугульдейской перемычки оз. Байкал // Изв. ИГУ. Серия Наук о Земле. 2014. Т. 10. С. 57-66]. 
Vologina E.G., Sturm M., 2009. Typification of Holocene Deposits and Regionalization of the Baikal Basin. Geology and Geophysics 50 (8), 933-940 (in Russian) [Вологина Е.Г., Штурм М. Типизация голоценовых отложений и районирование бассейна озера Байкал // Геология и геофизика. 2009. Т. 50. № 8. С. 933-940].
Yada T., Nakamura T., Takaoka N., Takaaki N., Terada K., Yano H., Nakazawa T., Kojima H., 2004. The Global Accretion Rate of Extraterrestrial Materials in the Last Glacial Period Estimated from the Abundance of Micrometeorites in Antarctic Glacier Ice. Earth, Planets and Space 56 (1), 67-79 https://doi.org/10.1186/BF03352491.

\section{NIKOLAI I. AKULOV}

Doctor of Geology and Mineralogy

Institute of the Earth's Crust, Siberian Branch of RAS

128 Lermontov St, Irkutsk 664033, Russia

e-mail: akulov@crust.irk.ru

ORCID: 0000-0002-5268-5465

\section{ELENA G. VOLOGINA}

Candidate of Geology and Mineralogy

Institute of the Earth's Crust, Siberian Branch of RAS 128 Lermontov St, Irkutsk 664033, Russia

e-mail: vologina@crust.irk.ru

\section{LYUDMILA A. PAVLOVA}

Candidate of Geology and Mineralogy

A.P. Vinogradov Institute of Geochemistry, Siberian Branch of RAS

1A Favorsky St, Irkutsk 664033, Russia

e-mail:pavpla@mail.ru

\section{SVETLANA S. VOROBYOVA}

Candidate of Biological Sciences

Limnological Institute, Siberian Branch of RAS

3 Ulan-Batorskaya St, Irkutsk 664033, Russia

e-mail: lana@lin.ru

\section{НИКОЛАЙ ИВАНОВИЧ АКУЛОВ}

докт. геол.-мин. наук

Институт земной коры СО РАН

664033, г. Иркутск, ул. Лермонтова, 128, Россия

\section{ЕЛЕНА ГЕННАДЬЕВНА ВОЛОГИНА}

канд. геол.-мин. наук

Институт земной коры СО РАН

664033, г. Иркутск, ул. Лермонтова, 128, Россия

\section{ЛЮДМИЛА АНАТОЛЬЕВНА ПАВЛОВА}

канд. геол.-мин. наук

Институт геохимии им. А.П. Виноградова СО РАН 664033 г. Иркутск, ул. Фаворского, д.1А, Россия

\section{СВЕТЛАНА СЕМЕНОВНА ВОРОБЬЕВА}

канд. биол. наук

Лимнологический институт СО РАН

664033, г. Иркутск, ул. Улан-Баторская, 3, Россия 